\title{
JAKIEJ FILOZOFII PEDAGODZY POTRZEBUJĄ? O POCZĄTKACH PEDAGOGIKI UNIWERSYTECKIEJ W KRAKOWIE
}

\author{
What kind of philosophy do pedagogues need? - The origins of university pedagogy in \\ Krakow
}

\begin{abstract}
$\mathrm{Su} \mathrm{m} m$ ary: The article is primarily concerned with the first three decades of the 19th $\mathrm{c}$. but it also refers back to the origins of the (reformed) University of Krakow, and to the times of activities of the Committee of National Education. It discusses historical events connected with the functioning of the university, and the philosophy and pedagogy taught there. In those times the lectures were based on the then novel assumptions found in foreign manuals. The title of the article is a paraphrase of the title of Rev. K. Jaroński's lecture: 'What kind of philosophy do Poles need?' delivered a year after the University of Krakow was once again able to lecture in the Polish language. The text places particular emphasis on the essential connection between pedagogy and philosophy which is the source of necessary axiological fundamentals for the former. At that time, in Krakow there was a heated 'debate about Kant', the best known and accepted argument being that presented by 'the Scottish school' or realistic 'common sense philosophy'.
\end{abstract}

Key w ord s: reform, knowledge, ethical perfection (virtue), philosophy, social practice

\section{Wstęp}

Pierwsze dziesięciolecia XIX wieku odznaczyły się szczególną aktywnością filozoficzną myślicieli polskich, którzy zastanawiali się nad tym, jakiej filozofii Polacy potrzebują. Tytuł tego artykułu stanowi więc parafrazę, a zarazem nawiązanie do konkretnego klimatu towarzyszącego ówczesnym rozważaniom. Nawiązanie to ma wielowarstwowy wymiar. W sensie najściślejszym chodzi tutaj bowiem o tytuł mowy wygłoszonej przez księdza Feliksa Jarońskiego (1777-1827), profesora uniwersytetu, 
15 października 1810 roku w Akademii Krakowskiej ${ }^{1}$ Okoliczności wygłoszenia tej mowy są szczególne, ponieważ obchodzono wtedy rocznicę ustawy wiedeńskiej, w oparciu o którą na katedry uniwersyteckie powrócił język polski. Feliks Jaroński postawil pytanie „Jakiej filozofii Polacy potrzebują?” ponad dwieście lat temu, a sytuacja dotycząca kultury umysłowej wówczesnej Polsce, pozbawionej politycznego bytu, przydawała jego wystąpieniu dramatyzmu. Nie zamierzam tutaj porównywać czy oceniać stopnia trudności, przed jakimi stawały ówczesne i dzisiejsze instytucje naukowe oraz środowiska akademickie, lecz ograniczę się do niektórych wątków treści tego wystąpienia. Mają one bowiem wymiar ponadczasowy, jakkolwiek zawsze znajdują wyraz w konkretnej sytuacji historycznej.

Tytułowe pytanie mowy Feliksa Jarońskiego uderzyło swoją lapidarnością i niewyczerpaną aktualnością Władysława Tatarkiewicza, kiedy pracował nad wyborem tekstów polskich myślicieli, które powstawały w pierwszych trzech dziesięcioleciach XIX wieku. Dlatego całemu zbiorowi nadał taki właśnie tytuł: Jakiej filozofii Polacy potrzebują?2 We „Wstępie” doń napisał między innymi: „Dzieje filozofii w Polsce nie znają polemiki bardziej zaciętej, jak ówczesna polemika o Kanta."3 Być może więc argumenty wtedy wysuwane przysłużą się do wyjaśnienia podstaw filozoficznych dzisiejszej pedagogiki, nawiązującej nader chętnie oraz czasami bezkrytycznie do propozycji filozoficznych królewieckiego mędrca.

Podobnie sformułowane pytanie stało się kilka lat temu punktem wyjścia dla rozważań na temat współczesnego stanu polskiej filozofii. Ewa Starzyńska-Kościuszko podczas sesji plenarnej VII Seminarium Historyków Filozofii Polskiej, które odbyło się na Uniwersytecie Warszawskim 22 września 2014 roku, wygłosiła referat na temat: „Jakiej filozofii potrzebują dzisiaj Polacy?”, nawiązując właśnie do wyżej wspomnianego tekstu Feliksa Jarońskiego. Powiedziała wtedy między innymi: „[...] główne przesłanie mowy Jarońskiego zaskakująco współbrzmi z argumentami, jakie dzisiaj wysuwamy, broniąc statusu filozofii na polskich uniwersytetach. Uzasadnienie tezy o konieczności nauczania filozofii w wystąpieniu Jarońskiego i obecnie publikowanych tekstach jest identyczne. Kultura i społeczeństwo potrzebuje filozofii, bo rzeczywistość wymaga nieustannego namysłu i oglądu ze strony rozumu, bo filozofia tworzy poznawczy i aksjologiczny fundament, bez którego grozi nam «zdziczałość i barbarzyństwo»."4 Przytoczona wypowiedź stanowi bardzo dobry punkt wyjścia do snucia refleksji na temat współczesnych związków filozofii

\footnotetext{
${ }^{1}$ Nazwa „Uniwersytet Jagielloński” funkcjonuje od roku 1817. Na początku XIX wieku funkcjonowały nazwy: „Szkoła Główna Krakowska” albo „Uniwersytet Krakowski”.

${ }^{2}$ Jakiej filozofii Polacy potrzebują?, wyb. i wstęp Władysław Tatarkiewicz (Warszawa: PWN 1970).

${ }^{3}$ Tamże, XXV. Por. też: „[...] sprawa kantyzmu w Polsce jest sporna. Jedni z ówczesnych filozofów polskich chwalili Kanta, ale inni potępiali z namiętnością nie spotykaną w innych krajach, mieli go wręcz za wroga nauki i ludzkości. Nieprzejednanym wrogiem był Jan Śniadecki, ale wcześniej już napaści przeciw niemu wyszły od Jarońskiego; a diatryby obu brzmią prawie identycznie, tak samo nazywają go «apokaliptycznym». Atak Jarońskiego był z r.1811. Śniadecki zaś rozpoczą swą filozofię przeciw Kantowi w roku1813. Jaroński wystąpił najostrzej w raporcie uniwersyteckim z roku 1810; potem w pracach drukowanych wyrażał się łagodniej, natomiast Śniadecki do końca był nieprzejednany".

${ }^{4}$ Źródło: https://www.filozofiapolska.pl/warszawa2014/program.html; [dostęp: 28.V.2016].
} 
i pedagogiki. Bez jasno określonej aksjologii, uzasadnionej filozoficznie, trudno sobie bowiem wyobrazić wypełnienie istotnej misji kulturowej stanowiącej sens istnienia pedagogiki jako wiedzy oraz umiejętności.

Źródeł pedagogiki uniwersyteckiej w Polsce, zarówno w kontekście przekazywania wiedzy, jak i odpowiedniego wychowywania młodzieży, można z pewnością szukać we wszelkich wysiłkach profesorów i nauczycieli związanych z życiem uniwersyteckim od początków jego istnienia wczternastowiecznym Krakowie, a wkrótce potem pod rządami Jagiellonów. Od początku próbowano tutaj łączyć nauczanie i wychowywanie z refleksją na temat, jak mówiono jeszcze w XIX wieku, „ostatecznych przeznaczeń człowieka”. Scienciae winna bowiem łączyć sapientia.

Jako przykład łączenia wiedzy i doskonałości moralnej, czyli cnoty, może posłużyć symbolika towarzysząca nadaniu magisterium sztuk wyzwolonych na (odnowionym) Uniwersytecie Krakowskim: „Najpierw promotor wręczał magistrantowi zamkniętą księgę, która miała go ostrzegać przed zbytnim ufaniem swojej pamięci, a zachęcać do uciekania się do ksiąg, stanowiących «vasa memorie». Potem nakładał mu biret na znak władzy i godności, zaś na środkowy palec pierścień złoty, symbol cnoty i czystości; na palec środkowy dlatego, aby pamiętał, że «virtus est in medio». W dalszym ciągu promotor podawał magistrantowi księgę, ale otwartą, by jawnie nauczał swoich uczniów. Z kolei ogłaszał go magistrem artium i przyznawał mu prawo wykładania i prowadzenia dysput na Uniwersytecie Krakowskim i na wszystkich innych. [...] Wbrew ogólnemu przeświadczeniu o wszechwładnym panowaniu łaciny na naszym Uniwersytecie, w mowach promocyjnych Łukasza [z Wielkiego Koźmina] (ale także i innych mistrzów sztuk wyzwolonych) natrafia się na wtrącone poszczególne słowa polskie i ich interpretację. Trzeba przyznać, że ta interpretacja bywała nieraz bardzo sztuczna i nieudolna, miała ona jednak cel dydaktyczny, gdyż Koźmińczyk posługiwał się nią głównie po to, by zachęcić promowanego do dalszych postępów w nauce i cnocie.”5

Zatem w Polsce od początku nauczaniu uniwersyteckimu towarzyszył program łączenia „nauki i cnoty”, a więc pogłębiania wiedzy oraz doskonałości etycznej. Scientiae wymagały poszukiwań nowych metod i obszarów badawczych, rozwiązywania konkretnych zagadnień, natomiast mądrość miała przejawiać się w praktyce, uczony winien być także przykładem człowieczeństwa.

\section{Historia jako magistra vitae}

Początki pedagogiki uniwersyteckiej w Krakowie, o których tutaj będzie mowa, dotyczą mniej więcej pierwszych trzech dziesięcioleci XIX wieku. Aby sens niektórych wydarzeń oraz postanowień stał się bardziej wyraźny, trzeba przypomnieć krótko to,

\footnotetext{
5 Maria Kowalczyk, „Mowy i kazania uniwersyteckie Łukasza z Wielkiego Koźmina”, w: Colligite fragmenta ne pereant... Studia zdziejów Uniwersytetu Krakowskiego w średniowieczu (Kraków: Towarzystwo Naukowe Societas Vistulana 2010), 75-76.
} 
co działo się nieco wcześniej na krakowskiej uczelni. Wcześniej istniały już bowiem seminaria nauczycielskie zakładane przy okazji prac KEN przez Hugona Kołłątaja. Przy Szkole Głównej Krakowskiej funkcjonowało takie seminarium, a problemami pedagogicznymi zajmowali się także filozofowie ${ }^{6}$.

Najpierw więc pojawił się projekt organizowania w ścisłej łączności ze Szkołami Głównymi, czyli Szkołą Główną Krakowską oraz Szkołą Główną Wileńską seminariów nauczycielskich. Pisze o tym Józef Sołtykowicz przy okazji omawiania programu reform przeprowadzanych przez Komisję Edukacji Narodowej: „Co do Nauk; każda Szkoła Główna dzieliła się na dwa wielkie oddziały, Fizyczny i Moralny: pierwszy, zawierał w sobie Szkołę Matematyczną, Fizyczną i Lekarską; drugi Szkołę Filozofii, Prawa, Teologii i Literatury, do której należały języki umarłe, Oryentalne i żyiące Europeyskie. Przy każdey Szkole Głównej było założone Seminaryum Kandydatów sposobiących się do Stanu Nauczycielskiego; gdzie nie tylko Młodzież akademicka, ale także różnych Zakonów uzdatniała się na Proffessorów publicznych. Każda Szkoła Główna w widoku doglądania iednostayności planu edukacyynego wysełała corocznie Wizyty do szkół sobie podległych tak Akademickich jak i Zakonnych; a w miarę potrzeby, opatrywała wszystkie wychodzącemi z swego Seminarium Nauczycielami.

Program zakładania seminariów nauczycielskich towarzyszył od początku projektom głębokiej reformy szkolnictwa, polegającej między innymi na ustaleniu jednolitych programów nauczania. Wiązało się to z uprzednią reformą Szkoły Głównej Krakowskiej, którą przeprowadził Hugo Kołłątaj, przy czym już wówczas nie wszyscy optowali za jednolitym programem. Pisze na ten temat Sołtykowicz: „[...] wielu nawet mniemało że bez tego punktu zjednoczenia [chodzi o ujednolicenie programów nauczania] Edukacya powszechna obejśdźby się bezpiecznie mogła. Inni, spodziewali się temu zaradzić przez przekształcenie Zakonu Piiarskiego, dawszy mu większą obszerność i założywszy w nim Seminaryum przyszłych Nauczycielów.”"

\footnotetext{
${ }^{6} \mathrm{Na}$ ten temat możemy przeczytać we współcześnie wydanej pozycji: „Dla adeptów zawodu nauczycielskiego powołano w r. 1780 specjalne seminarium, którego rektorem został pijar Antoni Popławski. Panujący w nim klasztorny reżim, obowiązek noszenia sukni kleryckiej, nie przygotowywały do samodzielnego życia w społeczeństwie świeckim. Zmiany na lepsze nastąpiły w 1783 r., gdy opiekunem seminarium został profesor prawa rzymskiego, ks. Bonifacy Garycki. System klasztorny został wówczas zniesiony, a kandydatom pozwolono zamieszkać w bursie. W zreformowanej Szkole Głównej przyszli nauczyciele wyrastali w duchu racjonalizmu, co doprowadziło wielu z nich do obojętności religijnej. $Z$ tego powodu za rektoratu następcy Kołłątaja, Feliksa Oraczewskiego, wprowadzono nadzór nad moralnością kandydatów i obowiązkowe praktyki religijne.” Por. Krzysztof Stopka, Andrzej K. Banach, Julian Dybiec, Dzieje Uniwersytetu Jagiellońskiego (Kraków: Wydawnictwo UJ 2000), 83.

${ }^{7}$ Tekst przytaczam w kształcie z 1810 roku; jest to fragment pisma Józefa Sołtykowicza, O stanie Akademii Krakowskiey iopublicznych a mianowicie uczonych pracach akademików [dedykowany] „Nayjaśnieyszemu Panu Fryderykowi Augustowi Królowi Saskiemu Xiążęciu Warszawskiemu na posiedzeniu publicznem Szkoły Główney dnia 10 maja roku 1810 podany przez J.Soltykowicza (c.d.) „NN.WW. i F.D. i W, NN. D w Krakowie 1810 w Drukarni Groblowskiej”, 82-83. Tenże Józef Sołtykowicz „miał za sobą studia w Akademii Krakowskiej, gdzie uzyskał doktorat filozofii wr.1778, i długie lata pracy pedagogicznej w szkołach narodowych KEN jako nauczyciel prawa”. Por. Mirosława Chamcówna, Kamilla Mrozowska, Dzieje Uniwersytetu Jagiellońskiego w latach 1765-1850 (Kraków: PWN 1965), 80.

${ }^{8}$ Soltykowicz, O stanie, 78 .
} 
Potrzeba kształcenia całego zastępu pedagogów, przygotowanych do realizowania nowego programu nauczania wynikała zarówno zideałów epoki oświecenia, jak i ze zrozumienia potrzeb zagrożonego w swoim bycie narodu: „Zgoła trzeba było tak wiele i tak okropnych na Naród nasz wypadków, aby Polacy nad ostatnią już postawieni przepaścią ocucili się z długiego swego letargu i pomyśleli o jedynym śrzodku ratowania się, to jest gruntownem Oświeceniu i dobrem Wychowaniu nowego Pokolenia" - zauważa autor dzieła pt. O stanie Akademii Krakowskiej ${ }^{9}$. Język profesora Soltykowicza brzmi dzisiaj miejscami anachronicznie, ale treści w nim wyrażone pozostają w pełni zrozumiałe.

KEN doprowadziła, jak wiadomo, do głębokiej rekonstrukcji Uniwersytetu Krakowskiego. Zdecydowanemu przekształceniu uległa dotychczasowa struktura oraz organizacja nauczania, zmieniły się także przedmioty, a niektóre po prostu zostały wyrzucone z uczelni. Przede wszystkim zamknięto Wydział Filozoficzny, który tradycyjnie stanowił wstęp do dalszego nauczania. Programy zostały dostosowane do różnych kategorii studiującej młodzieży, w zależności od rodzaju obranego zawodu. Inaczej więc uczono prawników, inaczej lekarzy, księży, a także przyszłych geometrów. Nie wolno było dyktować wykładów, które prowadzone miały być po polsku, ale w oparciu o podręczniki, które powstały na zachodzie Europy. Nie wolno było dawać studentom skryptów do odpisywania. Nie było tradycyjnych dyskusji i ćwiczeń, za to przyjęto jako regułę w programie studiów nauczycielskich odbywanie publicznych popisów.

Pierwsza reforma Kołłątaja w 1778 roku sprawiła, że zamknięto osiem $\mathrm{z}$ dziesięciu funkcjonujących Katedr Filozofii, a druga reforma doprowadziła do zamknięcia także dwóch pozostałych. Niektóre z tych zmian i związane z nimi zakazy mogą dziwić, a w każdym razie wydają się niezrozumiałe; z perspektywy kilku stuleci zlikwidowanie katedr, na których wykładano filozofię w duchu scholastycznym, a tym samym brutalne przerwanie wielowiekowej tradycji uniwersyteckiego nauczania filozofii klasycznej w Krakowie budzi sprzeciw. Reforma ówczesna nie powinna była lączyć się z burzeniem starego porządku, „czcigodnej budowy wieków średnich.” Nadto w „zreformowanym” programie kształcenia nauczycieli znalazło się dużo więcej miejsca na kształcenie nastawione na zewnętrzny efekt, było w nim więcej popisowej retoryki kosztem filozofii. Te zmiany i zależności stanowią od dawna przedmiot badań historyków nauki i oświaty w Polsce ${ }^{10}$.

Z wydanej w 1965 r. monografii, pt. Dzieje Uniwersytetu Jagiellońskiego $w$ latach 1765-1850 możemy się dowiedzieć, jak wyglądały pierwsze lata XIX wieku

\footnotetext{
${ }^{9}$ Tamże, 72.

${ }^{10}$ Por. „Druga część [chodzi o spuściznę pozostałą po H. Kołłątaju] obejmuje mowy, memoryjały, projekta i pomniki historyczne, tyczące się spraw komissyi edukacyjnej, reformy szkół w ogóle a szczegółowo reformy akademii krakowskiej z lat 1777 do 1788. Są tu nader wielkiej wagi listy ks. H. Kołłątaja do księdza Hołowczyca i ks. Prymasa Michała Poniatowskiego pisane, w przedmiocie urządzenia szkoły głównej, i zdanie sprawy złożone przez Ignacego Potockiego komissyi edykacyjnej o wizycie ks. H. Kołłątaja w akademii krakowskiej [...]” - Rękopismy Towarzystwa Naukowego „systematycznie zestawione” przez Władysława Seredyńskiego (Kraków 1869), VI.
} 
na tej uczelni: „Wybuch powstania kościuszkowskiego i jego klęska, która pociągnęła za sobą upadek państwa polskiego, były też kresem działalności Komisji Edukacyjnej i postawiły pod znakiem zapytania dalszy byt Uniwersytetu. Wprawdzie starania wysłanych do Wiednia profesorów: Śniadeckiego i Bogucickiego, zapobiegły natychmiastowej kasacie uczelni, jednakże lata następne przyniosły stopniowe usuwanie z katedr polskich profesorów, a wreszcie wr. 1805 przeniesienie do Krakowa niemieckiej kadry profesorskiej ze Lwowa."11

Profesorzy, którzy wówczas przybyli, wykładali po niemiecku, ponieważ lwowski uniwersytet miał być z założenia centrum germanizacji. W Krakowie lata germanizacji przeplatały się w wieku XIX z okresami „oddechu”, kiedy można było się uczyć i wykładać wjęzyku polskim. Zależało to zarówno od wydarzeń historycznych, jak i od nieustannie czynionych starań wielu osób, związanych z polską nauką i szkolnictwem.

Kiedy Józef Soltykowicz omawiał dzieje seminariów nauczycielskich, związanych z działalnością KEN, na początku wieku XIX w epoce zaborów wszystko, co polskie, stawało się mniej lub bardziej podejrzane dla przedstawicieli ówczesnych rządów. Dedykowanie podobnych relacji i prac ówczesnym władcom, tak, jak on sam to uczynił12 miało za zadanie przełamywanie ich niechęci i oporów oraz zachętę do życzliwego pochylenia się nad sprawami polskiego szkolnictwa, począwszy od uniwersyteckiego.

Początek wieku stał się okresem intensywnej germanizacji uniwersytetu, nie tylko przez niemieckojęzyczną kadrę profesorską, sprowadzoną głównie ze Lwowa (nauczano zresztą również po lacinie), lecz także poprzez zmiany związane z radykalnym ukróceniem uniwersyteckiej autonomii przejawiającej się wtedy także w niezależności finansowej. „Przyrzeczenie cesarskie dane Śniadeckiemu w Wiedniu, iż uniwersytet w Krakowie nie ulegnie likwidacji, nie oznaczało aprobaty dla modelu uczelni zreformowanej za czasów Hugona Kołłątaja. Dla Austrii był to model uniwersytetu nie do przyjęcia, którego nie zamierzała tolerować w granicach swego państwa. Był on zaprzeczeniem ideału, do jakiego już w fazie końcowej zmierzały reformy szkolnictwa wyższego w Austrii. Rozpoczęte jeszcze za czasów cesarzowej Marii Teresy i Józefa II, doprowadziły na przełomie XVIII i XI stulecia do ukształtowania wAustrii modelu uniwersytetu całkowicie podporządkowanego państwu absolutnemu i jego celom, skrępowanego na co dzień w swej działalności szczegółowymi przepisami administracyjnymi i zależnego finansowo od kasy państwowej' - zauważa jeden z autorów współczesnej książki pt. Dzieje Uniwersytetu Jagiellońskiego ${ }^{13}$.

\footnotetext{
${ }^{11}$ Chamcówna, Mrozowska, Dzieje, 61: „Ostatni protokół z obrad Szkoły Głównej Krakowskiej, toczonych w gorączkowej już atmosferze, ale jeszcze w państwie niepodległym, nosi datę 16 marca 1794. Następne posiedzenie odbyło się już pod okupacją pruską 1 października 1795.” Okupacja pruska z początkiem roku 1796 zamieniła się na austriacką. 5 stycznia 1796 roku Austriacy przystąpili do organizowania nowego okręgu, tzw. Galicji Zachodniej.

${ }^{12}$ Sołtykowicz dedykował wszak swoją książkę „Najjaśneijszemu Panu Fryderykowi Augustowi”.

${ }^{13}$ Por. Banach, Dzieje, 87.
} 
W roku akademickim 1804/o5 powołano do istnienia Katedrę Religii (na Wydziale Filozoficznym), na której nauczał benedyktyn, o. Wiktor Locher, w języku niemieckim. Około pięciu lat, od roku 1801 do 1806 , trwały przekształcenia wewnątrz krakowskiej uczelni, czynione przez austriackie władze, których celem było upodobnienie struktury uniwersytetu do austriackich instytucji naukowych. Po roku 1809 powrócił na katedry język polski, a przy tej okazji opuścili rychło Kraków zatrudnieni tutaj profesorowie niemieckojęzyczni. Pojawił się problem szybkiego znalezienia odpowiednich następców.

Dopiero w roku 1833 przy Wydziale Filozoficznym powstała Katedra Religii, Pedagogiki i Języka Greckiego, nawiązująca do „Katedry Religii” z początku wieku. Wtedy właśnie wprowadzono zajęcia z pedagogiki, jak na to wskazywała nazwa nowo powołanej do życia katedry. Jako zastępca profesora w 1834 roku został w niej zatrudniony Leon Laurysiewicz ${ }^{14}$. Nie znaczy to, że wcześniej nie było wykładów z zakresu pedagogiki - prowadził je przybyły ze Lwowa niemieckojęzyczny profesor filozofii Wacław Voight, o którym jeszcze będzie mowa poniżej.

Zaletą reform przeprowadzonych przy okazji działalności KEN było powiązanie szkolnictwa wyższego ze szkołami średnimi, nad którymi miano sprawować pieczę i kontrolę; celem było zachowanie odpowiedniego poziomu nauczania, a także realizowanie wyznaczonego programu. Miało to swoje zalety, jak nastawienie przyszłych absolwentów, zarówno szkół średnich, jak i wyższych, do praktycznej działalności, w tym do realizowania zadań obywatelskich. Reformy austriackie z początku XIX wieku pozrywały te więzi, usiłując stworzyć model wykształcenia wyższego oparty na własnych wzorach, we własnym języku.

\section{Filozofia}

Jakiej więc filozofii potrzebują Polacy i co na ten temat mieli do powiedzenia polscy profesorowie uniwersyteccy po roku 1809? Według Tatarkiewicza filozofia polska tego okresu miała charakter przygotowawczy oraz „przejściowy” - stawiano jej maksymalistyczne cele, formułowano fundamentalne pytania, natomiast wstrzymywano się z definitywnymi rozwiązaniami własnego autorstwa. Szukano ich za to whistorii, co Tatarkiewicz gotów jest łączyć z eskapizmem - zapewne niesłusznie. Tradycyjne zainteresowanie filozofią starożytną, na przykład pismami Cycerona, wynikało z równie tradycyjnych poszukiwań ustalonych wzorów etycznych i obywatelskich, sprawdzonych przez wieki. A poza tym już samo poprawne logicznie postawienie zagadnienia i sformułowanie pytania stanowi o sukcesie związanym z poszukiwaną odpowiedzią. Poprawnie zadane pytanie wskazuje odpowiedni obszar poszukiwań, ich dziedzinę. Wspólna praca nauczyciela i uczniów nie dotyczyła poza tym wyłącznie logiki i poprawności formalnej danej kwestii, lecz z pewnością również samej treści pytania. To prawda, czasami kończące rozważania konkluzje osoby

\footnotetext{
${ }^{14}$ Kontrkandydatem był Feliks Godziemba Sosnowski. Por. Archiwum UJ, WF I 46. Leon Laurysiewicz (1798-1854) w roku 1823 przyjął święcenia w obrządku grecko-katolickim. Dwa lata później objął probostwo parafii grecko-katolickiej im. św. Norberta w Krakowie.
} 
prowadzącej zajęcia według starych zasad, jeszcze sprzed reformy KEN, mogły były zwalniać ucznia od dalszego wysiłku intelektualnego, skoro osiągnięto już zadowalający wynik. Jerzy Samuel Bandtke, późniejszy krakowski profesor, napisał w swoim programie wykładów: „nauczyciel pokazuje tylko drogę, uczeń sam dalej na niej postępować powinien."15

Samodzielność poszukiwań, a przy tym sięganie do doświadczenia, szukanie racji z równoczesnym oparciem się na zdrowym rozsądku: ten common sense wskazuje na istotne związki i upodobania tamtejszych myślicieli do typu filozofowania właściwego „szkole szkockiej”16. Jej charakterystycznym wyróżnikiem był podwójny realizm: po pierwsze, przyjmowano, że rzeczywistość istnieje bez względu na to, czy jest poznawana, a po drugie, że poznajemy realne przedmioty, a nie ich idee w naszym umyśle. Obowiązywał więc także realizm poznawczy. Oprócz doświadczenia składnikiem poznania są, wedle założeń filozofii „zdrowego rozsadku”, również podstawowe i powszechne intuicje, na przykład te dotyczące istnienia przedmiotów wokół nas oraz innych ludzi podobnych do nas w istotny sposób w swoim człowieczeństwie. To wychodzenie w poznaniu od doświadczenia, którego centrum jest konkretny czlowiek, stanowi o humanistycznych tendencjach funkcjonujących w nauczaniu tamtejszego uniwersytetu. Julian Romuald Czermiński (1773-1830) pisał: „Czczą jest wiadomość nie mająca na celu udoskonalenia lub polepszenia bytu człowieka”. Oprócz praktycyzmu, cechą tamtej filozofii był więc także humanizm przejawiający się w poszukiwaniu sposobów oraz środków, by „udoskonalić byt człowieka”. To właśnie było głównym celem wysiłków filozoficznych oraz naukowych.

Podobna tendencja funkcjonowała w środowisku uniwersyteckim dużo wcześniej, przejawiając się ogromną estymą i poważaniem, jakim otaczano w Polsce imię i twórczość Franciszka Bacona, o którym wyrażano się (z laciny): „Bako Werulamiusz”. Już w połowie XVIII wieku, w latach 1750-1755, profesorem krakowskiej uczelni był Marcin Świątkowski, który jako autor dzieła pt. Prodromus Polonus (wydanego w 1760 roku) propagował nową myśl „Werulamiusza”. Dzieło swoje oparł na zasadach jego filozofii, a nie na klasycznej scholastyce.

W kontekście historycznym początku drugiej dekady XIX wieku, wobec wcześniej przeprowadzanych procesów i zabiegów germanizacyjnych przedsięwziętych przez władze austriackie, za szczególną wartość polskiego filozofowania ksiądz profesor Feliks Jaroński uznał możliwość uprawiania filozofii w języku ojczystym. Pokreślił jej ważność, mówiąc: „[...] ta to jest nauka, w której złym wyrozumieniu lub nieznajomości wylęgać się zwykły wszystkie błędne

\footnotetext{
${ }^{15}$ Archiwum UJ, Program wykładów bibliografii z 23.IX.1811, za: Chamcówna, Mrozowska, Dzieje, 131. Tamże, 130: „Wśród wykładających na Wydziale Filozoficznym profesorów najwyższy poziom i najszersze ambicje naukowe reprezentowali: Jerzy Samuel Bandtkie, Karol Hube i Józef Łęski”.

${ }^{16}$ W Polsce najwybitniejszym przedstawicielem „szkoły szkockiej” był Michał Wiszniewski. „Sołtykowicz i in. - o szkole szkockiej wiedział na podstawie pracy J.M. de Gérando: Histoire comparée des Systems de philosophie, Paris 1804"; za: Wit Jaworski, Z dziejów filozofii w Polsce. 1804-1807. M.W.Voigt, F.Jaroński, J.Sottykowicz, F.Wigura (Kraków: 1997).
} 
mniemania polityczne i religijne [...].”17 A przy tym: „[...] ważne rzeczy nie igraszką bujnej wymowy, ale zgłębiającego rozsądku przedmiotem być powinny [...]."18 Uderza Jaroński w ton obywatelski, kiedy przypomina postać Sokratesa, który podkreślał, że powinniśmy się uczyć nie dla „szkoły”, lecz „dla życia”: „ «nie filozofujmy dla szkoły» mawiał Sokrates, najmędrszy i najpoczciwszy z Greków; «filozofujmy dla potrzeby społecznego życia»."19

Feliks Jaroński w swojej mowie przypomina, że - po usunięciu katedr filozoficznych z uniwersytetu (czyli Szkoły Głównej) przez KEN - „rząd zeszły austriacki, pod którego panowanie w roku 1796 dostała się tutejsza Akademia, najprzód katedrę logiki, a potem katedrę zwaną «Philosophia speculativa» zaprowadził [...]”. Nie ocenia tego bynajmniej negatywnie, ale, niestety, „[...] nauczyciele (co dowiedziawszy się o traktacie, którego dziś rocznicę obchodzimy, miejsca swe poopuszczali) nie polubili narodu i języka swych uczniów [...]." ${ }^{20}$ Chodzi o nauczycieli niemieckojęzycznych, którzy byli przede wszystkim narzędziami służącymi planom germanizacyjnym austriackiego rządu.

Jak więc Jaroński definiuje filozofię? Jak określa jej przedmiot? Poprzez odwołanie się do jej starożytnej definicji jako miłości mądrości, a także jako do zbioru wiadomości, „jakie miano o Bogu, człowieku i naturze, Rerum Divinarum humanarumque scientia." ${ }^{21} \mathrm{~W}$ takim razie jak Jaroński reaguje na filozofię mu współczesną, tę budzącą wtedy w Polsce tak gwałtowne kontrowersje, a więc kantyzm? Nie pomniejszając jego zasług22, mówi wprost: to nie jest filozofia dla Polaków! Motywuje to następująco: „Filozof Królewiecki nie w polskim pisał języku i nie w stylu dla nas Polaków teraz być pożytecznym mogącym.” ${ }^{3}$ „Nie zaczynajmy więc od Kanta, ale od naszej potrzeby.”24 Podobnie „nie potrzebują” Polacy Fichtego i Szellinga, przynajmniej chwilowo, jak zdaje się ostrzegać Jaroński. Nie wchodząc tutaj głębiej wjego myśl, zauważmy, że nie chodziło mu tutaj literalnie o język filozofowania, aczkolwiek trudności wyrażania filozoficznych pojęć w języku polskim sam doświadczał i twórczo, a nierzadko z sukcesem, nad tym pracował. Raczej wskazywał tutaj i podkreślał właściwą hierarchię zadań oraz inspiracji poznawczych:

\footnotetext{
${ }^{17}$ Feliks Jaroński, Jakiej filozofii Polacy potrzebują? Rozprawa na publicznym posiedzeniu Akademii Krakowskiej, dla obchodu pamiątki traktatu w Wiedniu 1809 zawartego i upamiętnienia wolności handlowej miasta Krakowa, dnia 15 października r. 1810 zebranym czytana (Warszawa: PWN 1970) 4.

${ }^{18}$ Tamże, 6. Zaraz potem przytacza Jaroński Cicerona: Istius modi res dicero ornate velle puerile est, docti et intelligentis viri. Pełny cytat: istius modi autem res dicere ornate velle puerile est, plane autem et perspicue expedire posse docti et intellegentis viri. - jest to fragment dzieła De finibus bonorum et malorum.

${ }^{19}$ Tamże.

${ }^{20}$ Tamże, 9.

${ }^{21}$ Tamże.

${ }^{22}$ Tamże, 11: „Poprawy Kanta, dobrze przyjęte od zagłębiać się lubiących roztrząsaczów, dały początek nowym pracom; wzbudziły Degeranda, Karpego i wielu innych, których czynne prace dotąd nie ustają i każą się spodziewać, że wkrótce będziemy mieli wydaną filozofię odpowiadającą we wszystkich częściach swego składu, istotnej potrzebie rodzaju ludzkiego".

${ }^{23}$ Tamże.

${ }^{24}$ Tamże, 12.
} 
filozofia powinna koncentrować się na „sprawach ludzkich i boskich”, a więc w kwestii „spraw ludzkich” odnosić się także do problemów społecznego życia, tu i teraz. Czy to jest słuszna postawa? Z pewnością nie „jedynie słuszna”, ale zapoznanie tej perspektywy może prowadzić do szczególnego eskapizmu. Nie tylko można przy tym utracić poczucie rzeczywistości, lecz także zlekceważyć kontakty z najbliższym otoczeniem.

Także współcześnie bywa, że ten i ów filozof dochodzi do przeświadczenia, iż uprawiać filozofię określonego typu można tylko w określonym języku. Zdarza się przy tym, że skutkiem tego nie tylko przestaje pracować nad wyrażaniem filozoficznych treści w języku ojczystym, lecz także język ten lekceważy jako rzekomo mniej „filozoficzny”.

\section{Pedagogika}

Ksiądz Józef Alojzy Putanowicz (1737- 1788), filozof, był także autorem rozprawki o treści pedagogicznej Litterae. Mores. Religio. Seu de triplici scopo iuventutis instituendae, wydanej w Krakowie w roku 1768. Szerzył w niej ideały wychowawcze bliskie tym, jakie realizowali w swoich szkołach pijarzy, to znaczy wychowanie młodego człowieka na dobrego chrześcijanina i obywatela.

W pierwszych latach XIX wieku łączność filozofii i pedagogiki uniwersyteckiej w Krakowie przejawiała się czasami „unią personalną”: otóż w roku akademickim 1807/08, kiedy wykłady z zakresu pedagogiki pojawiły się po raz pierwszy na krakowskim uniwersytecie, prowadzone były przez Wacława Voighta (1765-1830) profesora filozofii 25 . Pozytywnie odcinał się na tle innych ówczesnych pracowników tego wydziału. Kamilla Mrozowska pisze o nim, że był on: „[...] jedynym chyba profesorem w tym wydziale, który miał ambicje naukowe i szereg opublikowanych prac. Należał on do, nielicznych na gruncie Krakowa, reprezentantów neohumanizmu, czemu dał wyraz w swym studium o Arystotelesie oraz w pracy $O$ źródłach spokojności duszy ${ }^{26}$. Mimo nakazów władz w swych wykładach z filozofii opierał się na notatkach własnych, a w wykładach z pedagogiki na pracach Niemeyera, co świadczyło o jego dobrej znajomości ówczesnej literatury pedagogicznej ${ }^{27}$.

\footnotetext{
${ }^{25}$ Michał Wacław Voigt był od 1804 roku nadzwyczajnym profesorem logiki, metafizyki, etyki i pedagogiki na UJ. Do Krakowa przybył z Pragi. Od roku1809 pracował we Lwowie, w liceum, które w latach 1805-1817 działało w miejsce uniwersytetu. W Krakowie Voigt nauczał od 1804 roku, a w 1810 opuścił Kraków.

${ }^{26}$ Książka ta została napisana pierwotnie w j. niemieckim pod tytułem Die Art, wie die studierende Jugend aus der Philosophie gepruft u. classificirt zu werden pflegt (Lemberg 1811), a następnie przetłumaczona na j. polski przez Feliksa Słotwińskiego herbu Leliwa (1787-1863) jako Źródła spokoyności duszy które czlowiek w swym własnym umyśle znayduie, dla wewnętrznego zaspokoienia myślacych ludzi przez Michała Wacława Voigta w ięzyku niemieckim napisane; a przez Felikxa Stotwińskiego na ięzyk pols. przetożone, potrzebnymi uwagami i przypisami pomnożone, Kraków 1814.

${ }^{27}$ Chamcówna, Mrozowska, Dzieje, 99.
} 
Od tamtej pory wykłady z zakresu pedagogiki były zwykle odnotowywane w spisach zajęć mimo, iż często nie były opłacane, prowadzono je więc bezpłatnie. Ksiądz Feliks Jaroński wykładał „filozofię” i historię filozofii, a także pedagogikę i etykę. Pedagogika była obowiązkowym przedmiotem na trzecim roku studiów filozoficznych, ale tylko dla przyszłych nauczycieli i katechetów. Dla innych pozostawała przedmiotem nieobowiązkowym. Jako taka znalazła się pośród listy „przedmiotów nieobowiązkowych” na uniwersytecie przekształconym na modłę austriacką.

We wspomnianym powyżej, głównym dziele Voigta, austriacki filozof „starał się dać wyraz swemu światopoglądowi kojarzącemu klasyczną filozofię grecką, stoicką wykładnię cnoty z filozofią moralną i filozofią religii Kanta." ${ }^{28}$ Chociaż dzieło Voigta przetłumaczone wtedy na język polski przez Feliks Słotwińskiego uważane jest za ważne wydarzenie w historii recepcji filozofii kantowskiej w Polsce, to trzeba równocześnie zauważyć, że poglądy autora ewoluowały powoli ku stanowisku empirycznemu. Krytykował bowiem skrajny racjonalizm dlatego, że - jego zdaniem - prowadził on do sceptycyzmu. Filozofia Kanta służyła mu zaś przede wszystkim jako oparcie w zwalczaniu naturalistycznych poglądów oświeceniowych fizjokratów. Skutkiem naturalistycznych tendencji był ideał wychowawczy zredukowany do człowieka jako „wypolerowanego zwierzęcia”. Kant dostarczał argumentów na podkreślanie autonomii człowieka wobec przyrody, a jednak drzemały w nim różne siły, nie tylko władze poznawcze, lecz także władze sprawcze. Tymczasem w czasach mu współczesnych, jak zauważał Voigt, ekonomia polityczna wypierała filozofię i etykę. Kiedy napisał szkic „Jak dalece szkoły mogą mieć wpływ na ukształtownie ducha narodowego", który w tej formie, przetłumaczony na jezyk polski, ukazał się w Pamiętniku Warszawskim²9, w poglądach, jakie reprezentował, podkreślał zasady, które pozwalają patrzeć na niego przede wszystkim jako na humanistę.

Z kolei w Wilnie to Jan Śniadecki krytykował Kanta i kantyzm, nie zawsze sprawiedliwie, ale też czasami nader trafnie. Jego oddziaływanie na nauczanie w Krakowie było, jak to wynika ze źródeł, całkiem spore. Można powiedzieć, że najbardziej obawiał się wpływu filozofii kantowskiej na etykę młodego pokolenia. Jak komentował sto lat temu tę jego polemikę z kantyzmem S. Harassek, według Śniadeckiego u Kanta „Zasadniczym błędem etyki ma być to, że prawidła moralności wyprowadza «z rozumu, oderwanego od czucia, od rzeczy, od ludzi»; a ponieważ Kant uważa «byt rzeczy i świadectwo zmysłów jako pozory», a zatem wszystko podaje w niepewność, więc i etyka jego nie może nic wartać, bo, «gdzie nie masz prawdy ani pewności tam nie masz ani obowiązków, ani cnoty».”30

\footnotetext{
${ }^{28}$ Jaworski, $Z$ dziejów,12.

${ }^{29}$ Wacław Voight, „Jak dalece szkoły mogą mieć wpływ na ukształtownie ducha narodowego”. Pamiętnik Warszawski 12 (1819).

${ }^{30}$ Stefan Harassek, Kant $w$ Polsce. Przed rokiem 1830 (Kraków: 1916), 31. W wewnętrznych cytatach znajdują się fragmenty artykułu „O metafizyce” J. Śniadeckiego, III, 228.
} 
Wit Jaworski zaś zwrócił uwagę, iż Voigt próbował przełożyć „kantowską etykę moralności na etykę stosowaną - czyli na to, co Kant nazywał antropologią." ${ }^{11}$ Zafascynowany możliwościami, jakie daje ta myśl, dostarczając argumentów na autonomię człowieka wobec przyrody, z czasem coraz bardziej, jak się wydaje, skłaniał się ku krytyce skrajnego racjonalizmu.

\section{Podsumowanie}

Adam Ignacy Zabellewicz (1784-1831), związany z Uniwersytetem Warszawskim (wówczas „Królewsko-Warszawskim Uniwersytetem” powołanym do życia w roku 1818), wyróżniał „antropologię wyższą" jako część filozofii oraz „antropologię niższą" uprawianą jako dziedzina pozafilozoficzna. Ta „wyższa”, jak pisał: „,...] dochodzi, nie co przyrodzenie robi z człowieka, lecz co człowiek, jako rozumna i moralna istota, sam robi z siebie, a przynajmniej co zrobić może i powinien, i jakie jest jego przeznaczenie.”32 Natomiast jako część „antropologii niższej” wymieniał Zabellewicz psychologię empiryczną, zaznaczając, że zarówno psychologia uprawiana wten sposób, jak i oparta na niej pedagogika są wykładane jako „oddzielne umiejętności”. Jednak obie części nauki o człowieku, „niższą” i „wyższą”, wiązał w istotny sposób ich główny przedmiot, którym był sam człowiek. Filozofia i pedagogika pozostawały ze sobą w związku, nierozłącznej unii.

Ksiądz Feliks Jaroński, krakowski profesor teologii i filozof, w swoim wykładzie „Jakiej filozofii Polacy potrzebują?” zauważył między innymi: „Oświecone narody, nam dziś sąsiadujące, przekonały się o tych prawdach isą dla nas najwidoczniejszym przykładem, jak nagle światło nauk rozszerzyło się między nimi, skoro tylko ich mowa stała się mową nauczycielów i pisarzów. Próżno by chciano liczne podejmować koszta w rozszerzaniu światła u nas przytłumionego, gdyby nam chciano dać do szkół obcą mowę i obcych nauczycieli."33 Pisał to w kontekście polityki germanizacyjnej, ale odnosić się to może do każdego języka obcego. Oczywiście nie oznacza to, aby wykłady w Polsce nie mogły się odbywać przykładowo w języku angielskim, ale obcy język wykładowy powinien stanowić ubogacającą alternatywę dla wykładów po polsku, przy czym nigdy nie powinna to być alternatywa wykluczająca.

Jak zauważył w swoim „Wstępie” do cytowanego już tutaj kilkakrotnie zbioru polskich tekstów filozoficznych Władysław Tatarkiewicz, zasada omawianej epoki, którą starano się respektować w pismach (być może dlatego byli to oligografowie) brzmiała: „przede wszystkim - nie nudzić”, co także, trzeba przyznać, posiada walor ponadczasowy i ze wszech miar godne jest naśladowania zarówno $\mathrm{w}$ „przedmiocie filozofii”, jak wtedy pisano, jak i na gruncie pedagogiki.

\footnotetext{
${ }^{31}$ Jaworski, $Z$ dziejów, 21.

32 Adam Ignacy Zabellewicz, „Co to jest filozofia?”, w: Władysław Tatarkiewicz, Jakiej filozofii Polacy potrzebują? wyb. i wstęp tegoż (Warszawa: PWN 1970), 72. Zabellewiczowi proponowano w $1817 \mathrm{r}$. katedrę profesora filozofii w Uniwersytecie Krakowskim, której nie przyjąl, natomiast rok później otrzymał analogiczne stanowisko w Warszawie.

${ }^{33}$ Jaroński, Jakiej.
} 
Sensem wychowania człowieka jest, bodaj w pierwszym rzędzie, wypracowanie umiejętności życia w szerszej społeczności, w ludzkiej wspólnocie. Starożytne źródła dostarczają licznych wzorów takiego wychowania, a służyć temu miała także filozofia. Kiedy dwa tysiące lat wcześniej Cyceron przekonywał swoich rodaków do uprawiania refleksji filozoficznej, jako warunek konieczny zainteresowania praktycznych Rzymian filozofią wymieniał piękny styl wywodów, ich doskonałą literacko jakość. Sam d jako twórca dostarczył na to najlepszych wzorów.

Cytowany przez Jarońskiego kilkakrotnie Cicero byłby najlepszym wzorem do naśladowania również dzisiaj, nie tylko w kontekście języka i pięknego stylu. Chodzi tutaj bowiem o odpowiednio rzetelną recepcję wszystkiego, co pochodzi z innych kultur oraz o krytyczną ocenę tego, co uprzednio zostało zanalizowane. Początkiem tego procesu jest szerokie otwarcie się na cały kulturalny świat po to, żeby przyswoić sobie wszystko, co tylko jest wartościowe poza granicami własnego kraju. Przekładając obcy dorobek na język własny należy, w miarę możności, przy tłumaczeniu obcych pojęć używać do tego porównań i obrazów dobrze znanych. Punktem wyjścia powinny być jednak właściwie rozpoznane oraz dobrze przemyślane potrzeby własnej społeczności. Otwarcie poznawcze na świat, postawa naukowa nie oznaczają przy tym z pewnością kontestacji wszystkiego, co dotychczas wypracowano na „lokalnym” gruncie, zwłaszcza jeśli obszarem odniesienia nie jest pustynia, lecz bogata tradycja i wielowiekowa kultura, o tyle zapoznana, że w ostatnich stuleciach dotknęły ją liczne kataklizmy i wstrząsy. Trzeba powiedzieć wyraźnie, że dopiero świadomość własnej tożsamości kulturowej jest koniecznym warunkiem właściwie pojmowanej otwartości na inne kultury. To wszystko, co pochodzi z zewnątrz, aby mogło być dobrze wykorzystane, po prostu musi uprzednio przejść fazę konfrontacji ze wszystkim tym, co własne i dobrze rozpoznane jako obiektywnie cenne.

Streszczenie : Artykuł dotyczy przede wszystkim pierwszych trzech dekad XIX wieku, ale nawiązuje zarówno do początków (zreformowanego ) Uniwersytetu Krakowskiego, jak i do czasów działalności Komisji Edukacji Narodowej. Omówione zostały w nim, szkicowo, wydarzenia historyczne, które towarzyszyły funkcjonowaniu Uniwersytetu i rozwijanej w nim filozofii oraz pedagogiki, opartych na nowoczesnych (jak na owe czasy) założeniach oraz zagranicznych podręcznikach. Tytuł artykułu jest - nieprzypadkową - parafrazą wystąpienia jednego z ówczesnych profesorów krakowskich, ks. K. Jarońskiego, pt. „Jakiej filozofii Polacy potrzebują?” Zostało ono wygłoszone w rok po tym, jak na krakowskiej uczelni znów wolno było wykładać w języku polskim. Przedstawiony tekst podkreśla istotną łączność między pedagogiką a filozofią, dostarczającą pedagogice koniecznych podstaw aksjologicznych. W Krakowie prowadzono wówczas intensywne „spory o Kanta”, przy czym najbardziej znana i akceptowana była „szkoła szkocka” albo filozofia „zdrowego rozsądku” o realistycznym charakterze.

Słowa kluczowe: reforma, wiedza, doskonałość etyczna (cnota), filozofia, praktyka społeczna 


\section{Bibliografia}

Domański, Juliusz, Zbigniew Ogonowski, Lech Szczucki. Zarys dziejów filozofii w Polsce. Wieki XIII-XVII. Warszawa: PWN, 1989.

Stopka, Krzysztof, Andrzej K. Banach, Julian Dybiec. Dzieje Uniwersytetu Jagiellońskiego. Kraków: Wydawnictwo UJ, 2000.

Finkel, Ludwik, Stanisław Starzynski. Historia uniwersytetu Lwowskiego. Lwów: 1894.

Harassek, Stefan. Kant w Polsce. Przed rokiem 1830. Kraków: 1916.

Jaworski, Wit. Z dziejów filozofii w Polsce. 1804-1807. M.W. Voigt, F. Jaroński, J. Sottykowicz, F. Wigura. Kraków 1997.

Kowalczyk, Maria. Colligite fragmenta ne pereant... Studia zdziejów Uniwersytetu Krakowskiego $w$ średniowieczu. Kraków: Wydawnictwo TN SV, 2010.

Lipska, Helena, Kazimiera Tatarowicz. Bibliografia piśmiennictwa do dziejów Uniwersytetu Jagiellońskiego. Kraków: 1967-1987.

Chamcówna, Mirosława, Kamilla Mrozowska. Dzieje Uniwersytetu Jagiellońskiego w latach 176-1850. Kraków: 1965.

Putanowicz, Józef A. Litterae. Mores. Religio. Seu de triplici scopo iuventutis instituendae. Kraków: 1768.

Rękopismy Towarzystwa Naukowego. Opracowane („systematycznie zestawione”) Władysław Seredyński. Kraków: 1869.

Sołtykowicz, Józef. O stanie Akademii Krakowskiey i o publicznych a mianowicie uczonych pracach akademików. Kraków: 1810.

Studia z dziejów Wydziału Filozoficzno-Historycznego, red. Sylwiusz Mikucki. Kraków: 1967.

Tatarkiewicz, Władysław. Jakiej filozofii Polacy potrzebują? wyb. i wstęp tegoż. Warszawa: PWN, 1970. 